\title{
You're an Uncle Tom!: The Behavioral Regulation of Blacks on the Right Side of the Criminal Justice System Brando Simeo Starkey
}

\begin{abstract}
INTRODUCTION
"You're an Uncle Tom!" From within the black community harsher words are seldom exclaimed. Indeed, Uncle Tom is the most injurious pejorative blacks can sling at one another. No one is impervious. Many famous blacks, in fact, have stomached the heavy blow of this potent slur.

Booker T. Washington, for instance, was censured because the most influential black man of his day was thought to have violated the social norm that blacks must never relent to Jim Crow, disfranchisement and the complete racial domination of the late $1800 \mathrm{~s}$ and early $1900 \mathrm{~s} .{ }^{1}$ Thomas Miller, the president of a black college in Orangeburg, South Carolina, was his accuser. Miller indicted Washington for his supposed various crimes against the race. ${ }^{2}$ Washington was an "Uncle Tom," proclaimed Miller, who made "every attempt . . . to degrade and humiliate the Negro, to rob him of his civil and political rights, to curtail his educational privileges and opportunities, to reduce him practically to helpless and hopeless peonage and serfdom in the Southland."3
\end{abstract}

'F Visiting Assistant Professor, Villanova University School of Law. Harvard Law School, J.D., 2008; The Ohio State University, B.A., 2004. I would like to thank Regina Austin for reading a larger work on which this article is based. I'd also like to thank Penelope Pether for her helpful guidance. I'd also like to thank Amun Bashir for her great research assistance. I would also like to thank Ken Mack who has been extremely helpful for this overall project. On a personal note, I would like to thank my mom, dad, brother and Wendy Ferguson (my girlfriend). See BRANDO SIMEO STARKEY, UNCLE TOM \& SOCIAL NORMS IMPROVING LEGAL INTERESTS AND AFFECTING PUBLIC POLICY (forthcoming)[hereinafter STARKEY, UNCLE TOM \& SOCIAL NORMS], the book from which this paper is drawn. See HARRIET BEECHER STOWE, UNCLE TOM'S CABIN (1852), the novel from which the epithet was adapted. Uncle Tom has turned into the most pernicious epithet used in the black community. See Brando Simeo Starkey, Uncle Tom and Clarence Thomas Is the Abuse Defensible?, GEO J. L. \& MOD. CRIT. RACE PERSP.

(forthcoming) (arguing that Uncle Tom should not be abandoned or discarded); Brando Simeo Starkey, Jim Crow and Uncle Tom: Law and Racism's Impact on Black Culture,_Ala. C.R. \& C.L. L. Rev. (forthcoming).

1. See William Henry Ferris, The African Abroad 90-91 (1913).

2. See id.

3. Id. Most of the criticism directed at Washington was because he was considered a racial accommodationist as seen in his famous Atlanta Compromise speech. See also BOOKER T. WASHINGTON, UP FROM SLAVERY 160-164 (1993). Even still, Washington clandestinely funded a 
Marcus Garvey called W.E.B. Du Bois, perhaps the most abiding advocate for racial justice in American history, an Uncle Tom. ${ }^{4}$ Garvey remarked that the "effigy of Du Bois and his type should be placed alongside that of Uncle Tom, because as a fact he is of the same mentality." Garvey's critique was that while $\mathrm{Du}$ Bois cloaked himself in the accoutrements of a true race warrior, he actually "belong[ed] to that school of thought that would hitch the Negro onto the white man's coat tail with the hope that one day the Negro will put on the white man's cast-off coat." ${ }^{\prime}$ According to the nationalistic Garvey, Du Bois was a toady for whites and foundered at instilling race pride and self-reliance in blacks. ${ }^{7}$

Even Martin Luther King Jr. was taunted as an Uncle Tom for violating the social norms of 1960 s-era black nationalists. ${ }^{8}$ Malcolm X, Stokely Carmichael, H. Rap Brown, and LeRoi Jones all labeled King as an Uncle Tom. ${ }^{9}$ His critics invariably cited his non-violent resistance as supporting their charge of racial betrayal. ${ }^{10}$

But not just the famous have weathered the ominous Uncle Tom. ${ }^{11}$ Regular black folk too have been pelted with Uncle Tom accusations. Buck Stevens, for instance, a common black man, helped a white lynch mob capture Philip Gathers, a black man wanted for slaying a white woman. ${ }^{12}$ For his troubles,

successful challenge of peonage, Bailey $v$. Alabama and also helped in defeating a disfranchisement bill in the Georgia state legislature. 2 LOUIS R. HARLAN, BOOKER T. WASHINGTON: THE WIZARD OF TUSKEGEE, 1901-1915,250-251 (1983).; ROBERT J. NORRELL, UP FROM HISTORY: The Life of Booker T. WAShington 188-189, $405-406$ (2009); Pete Daniel, Up From Slavery and Down to Peonage: The Alonzo Bailey Case, 57 J. OF AM. HIST. 654, 668 (1970).

4. Wilson Jeremiah Moses, BLACK MESSIAHS aND UNCLE TOMS: SOCIAL AND LITERARY MANIPULATIONS OF A RELIGIOUS MYTH 142 (1993).

5. Id.

6. Marcus Garvey, The American Negro, The Black MAN, June 1935, at 5.

7. On another occasion, Garvey asserted that Du Bois tried "to be everything else but be a Negro. Sometimes we hear he is a Frenchman and another time he is Dutch and when it is convenient he is a Negro... Anyone you hear always talking about the kind of blood he has in him other than the blood you see, he is dissatisfied with something, and. . if there is a man who is most dissatisfied with himself, it is Dr. Du Bois." Elliot RudwiCk, W.E.B. DU BOIS: PROPAGANDIST OF THE NEGRO PROTEST 219 (1968). On this narrow point, Du Bois biographer David Levering Lewis vindicates Garvey's underlying message. Lewis writes "this subtext of proud hybridization is so prevalent in Du Bois' sense of himself that the failure to notice it in the literature about him is as remarkable as the complex itself." DAVID LEVERING LEWIS, W.E.B. DU BOIS: BIOGRAPHY OF A RACE 148 (1993).

8. Two Americas, Many Americas, WASH. Post MAG., Oct. 22, 1978, at 21.

9. $I d$.

10. King thought his militant detractors misunderstood his message. King argued for nonviolent resistance not nonresistance as his opponents often claimed. King wanted blacks to peacefully contest their subordination. He never encouraged blacks to sit idly and accept injustice. He simply disagreed with violent strategies, viewing them as immoral and unwise. MARTIN LUTHER King JR., THE AUTOBIOGRAPHY OF MARTIN LUTHER KING, JR. 266 (2001).

11. See generally Starkey, Jim Crow and Uncle Tom, supra note ' $F$.

12. Give Purse to Race Betrayer "Uncle Tom," Who Led Innocent Man to Mob, Rewarded by Lynchers, CHI. DEFENDER, July 3, 1920, at 1. 
after Gathers's lynching in the summer of 1920, local whites bestowed upon Stevens a cashier's check worth $\$ 10.11^{13}$ The Chicago Defender, a black newspaper, reported the events in an article entitled "Give Purse to Race Betrayer 'Uncle Tom,' Who Led Innocent man to Mob, Rewarded by Lynchers." "' Stevens' transgression was assisting in the lynching of a black man.

In 1932, similarly, the Baltimore Afro American, a black newspaper, rebuked "Uncle Tom" preachers from Tampa, Florida for directing blacks to continue patronizing segregated railroads. This criticism was based on the revelation that railroad companies provided these preachers with reduced fairs and "other concessions" in exchange for their support. ${ }^{15}$ A quid pro quo between clergymen and Jim Crow promulgators was a patent impropriety.

And in 1961, Rev. J. W. Jones, a black Baptist minister, strove to dissuade James Meredith from seeking to enroll in the all-white University of Mississippi. ${ }^{16}$ Jones opposed Meredith's aim because it, he estimated, "will cause a setback in harmony between white and [blacks]. He will be doing us harm. We will not be ready for a long time to try to compete on a fully equality basis." 17 Jones, for this, was dismissed as an "Uncle Tom" with a big mouth. ${ }^{18}$ Jones's error was similar to that of Washington; he exhibited timidity, not intrepidness, in the face of white supremacy.

In each of these narratives, the accusers believed that their targets were impeding the race's collective interests and employed the epithet Uncle Tom, which brands a person as a racial Judas. Uncle Tom, that is, is much more than an intra-racial slur that blacks have hurled around over the years whenever a group member has supposedly betrayed the race. Indeed, Uncle Tom is a vital component of a system of social norms - the rules that regulate behavior in groups that are enforced through sanction - in the black community that police racial fidelity. ${ }^{19}$ Indeed, blacks have monitored group fidelity through the management of "racial loyalty norms" throughout history.

Uncle Tom owes much of its significance to the cause of racial solidarity. By marshaling support for certain goals, racial solidarity provides blacks a path toward legal gains. By itself, it surely is not enough. In concert with other tools, however, racial solidarity can be extremely valuable. The Montgomery Bus Boycott, the 1960s sit-in movements and Project Confrontation in Birmingham in 1963 are perfect examples of racial solidarity, in tandem with other tools, helping produce civil rights victories. And even when it does not lead to

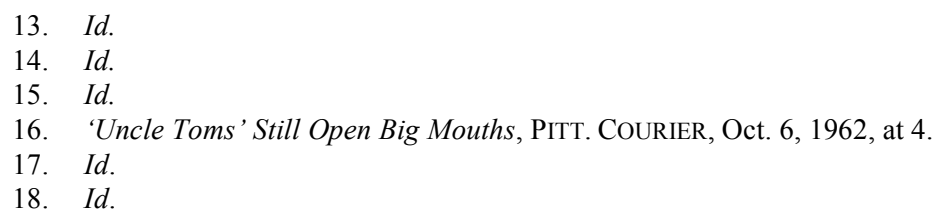


substantive legal gains as was true with the anti-lynching movement, racial solidarity in any event, has provided blacks with a starting point from which to resist their subordination. If racial solidarity is one in a set of various tools that helps blacks achieve legal goals, then social norms that encourage that solidarity are crucial.

The management of "constructive" social norms to police racial loyalty, by helping forge solidarity, can aid blacks in promoting their legal interests and in their ability to affect public policy. This is observable by following the history of Uncle Tom. A person, in other words, is called an Uncle Tom when he or she violates a racial loyalty norm that actually exists or that someone wants to exist. This signals to the rest of the black community to conform or else be punished. That is, the real power of Uncle Tom as a sanctioning device is the deterrent effect it has on the broader group. Shadowing Uncle Tom through black history helps us to understand where and how these norms were constructed, disseminated, applied, and enforced. From there, we can assess the propriety of these norms.

These norms generally fall into two groups: constructive norms and destructive norms. Constructive norms, on the one hand, help build racial solidarity by either penalizing individuals for consciously promoting the interests of the race's enemies, for exhibiting inexcusable meekness in the face of racism or for lacking concern for the race. "Destructive" social norms, on the other hand, discipline blacks for behaviors the race should permit. These "destructive" norms impede the cause of racial solidarity because they over-regulate behavior.

This Article's thesis is that as the endeavor of enforcing racial loyalty through social norms has continued, destructive norms have increasingly predominated over constructive ones. The best explanation for this is that norm managers are now less responsible. Previous enforcers tended to be more conscientious. This has been gradually less true, particularly in the last three decades. Uncle Tom has diverted from its past and is now frequently employed in situations that should never have led anyone to conclude that betrayal was afoot.

This Article demonstrates the veracity of this claim by investigating racial loyalty norm management in the context of blacks carrying influence within the criminal justice system. Two periods are discussed. From the 1960 s to the early 1970s, the black police officer was often targeted for asserted racial treachery. Blacks held an image of the white cop as an agent of brutality, racism and injustice. Black police officers, who were frequently deemed no different, were accused of violating racial loyalty norms. Uncle Tom accusations were the common penalty. Norm management during this period was generally constructive. That constructiveness, however, deteriorated in the ' $80 \mathrm{~s}$ and ' $90 \mathrm{~s}$. Then, the new influx of blacks who occupied positions of increased and varied authority from within the justice system quickly became vulnerable to racial 
treachery accusations as well. These norms, though, were decidedly more destructive than those of the previous generation.

This Article's thesis unfolds over the course of three Parts. Part I argues that racial loyalty norms can either be constructive or destructive and describes both how the former can aid the cause of racial solidarity and how the latter depresses collective action. Part II investigates the monitoring of blacks in criminal justice system contexts in the 1960s and the '70s and argues that the norm management during that period was predominantly constructive. During that period, police officers were the only blacks representing the race from within the criminal justice system in any nontrivial numbers. Some blacks, fueled by a supreme distrust of law enforcement, pressured black cops to resist being appropriated by the system by overlooking racist practices and becoming the agents of injustice that many white cops were viewed as. Black cops, considered amongst other blacks as being interchangeable with their worst white peers, were hit with Uncle Tom accusations. After the Civil Rights Movement, blacks pierced the glass ceiling, holding new occupations within the system. As before, some blacks attempted to define the contours of acceptable behavior through racial loyalty norm management. It is this later era, specifically the 1980 s and 1990s, which is the subject of Part III. The norm management of this period was far more destructive than in the previous one. Indeed, racial loyalty norm management has grown quite destructive. Many norms in the second period over-regulated black behavior, weakening, rather than strengthening the bonds of racial solidarity.

\section{CONSTRUCTIVE AND DESTRUCTIVE NORMS}

Racial loyalty norms arrange into two categories, constructive and destructive. ${ }^{20}$ Constructive norms promote racial solidarity by punishing treasonous behaviors that truly inhibit the goals of a racially unified people. Destructive social norms, however, discourage solidarity because they over-regulate behavior. These norms discipline actors for behaviors that are not treacherous. Group rules perceived as illegitimate and overbearing sour efforts to build racial solidarity. Thus, destructive norms have the perverse effect of alienating some blacks into rejecting the notion of racial solidarity altogether. ${ }^{21}$

\footnotetext{
20. Some social norms, theoretically, could be neutral but I'm not centrally focused on those.

21. But black solidarity should not be compulsory. If one wants to reject the notion that there is a group to which one owes obligation, they should be free to make that choice. And, more important, blacks must never criticize those who eschew racial solidarity. Their decision to "opt out," in other words, must not expose them to rebuke. To assess the propriety of social norm management throughout history, this book assumes that all of the persons discussed embraced notions of solidarity. At the same time, however, those who reject solidarity cannot seek to reap the benefits that the group may be able to confer on individual members. That is to say, blacks should not accept free riders. Thus, a public intellectual who has repudiated racial solidarity but later believes he has been the victim of racism must not be able to count on the broader community to
} 


\section{A. Constructive Norms}

There are three types of constructive racial loyalty norms. The first norm punishes blacks for consciously seeking to advance the enemies' interests. The second norm penalizes inexcusable meekness in the face of racism. And the third censures blacks for lacking concern for the race. Each norm provides an effective manner of encouraging racial solidarity. If the black community, for example, minimized the amount of blacks who violated these norms in, say, the 1940 s, the community would have better positioned itself to directly challenge Jim Crow. That is to say, adherence to these norms enhances blacks' capacity to direct legal triumphs. Let's examine these three constructive racial loyalty norms individually.

\section{Advancing Enemy Interests}

There are some obvious hypotheticals of a person consciously promoting enemy interests. A black person, for instance, who clandestinely works for the $\mathrm{Ku}$ Klux Klan and infiltrates a racial uplift organization to appease his Klan bosses, would obviously qualify. But let's take a step back. I use the word "consciously" for a reason. I am proposing something approaching intent, intent to aid. See, for example, a black prosecutor who seeks the death penalty for a black defendant charged with murder. The prosecutor should be exempt from condemnation even though an anti-black organization would likely cheer the decision. Thus, in that situation, there would need to be a closer connection between the motivation to seek the death penalty and the enemy's interest being promoted. The prosecutor, in other words, would have had to intend to please an anti-black organization with the decision to seek the death penalty. Accordingly, if the prosecutor was acting at the behest of white supremacists, then castigation should be swift.

But let's say that a black lawyer in the 1920s dismissed anti-lynching legislation as an unconstitutional abridgment of state's rights at a U.S. Senate hearing. Such a person would deserve public censure for treachery even if he is merely voicing his honest opinion. When blacks are being lynched throughout the South, flawed constitutional arguments, no matter how much they are sincerely believed, should not protect one from sanction. What is truly at work here is a sliding scale. The more people affected, the more severe the stakes, the lower a standard of intent is required. If a person champions a position obviously antithetical to blacks' interests, moreover, absolution is impossible.

take up arms in defense. By shunning the requirement to oppose anti-black racism, he has surrendered any claims to group benefits he might otherwise have had. There is, though, the issue of whether previous solidarity rejecters can have a change of heart and be acknowledged as participants in racial solidarity. I believe that persons should be given the opportunity to become part of the unit after having opted out. 
But does this mean that blacks can never work for anti-black organizations? The answer appears obvious. Of course, not! But the question is trickier upon closer inspection. In 1993, Anthony Griffin, a black attorney for the American Civil Liberties Union in Texas, received national attention after representing the head of the Texas Knights of the KKK, Michael Lowe. The Texas Human Rights Commission demanded that Lowe disclose his membership lists. Griffin was also the chief counsel to a local NAACP branch. The branch eventually fired him, citing a conflict of interest, of which there certainly was because the NAACP fights white supremacists and their organizations. Its chief counsel cannot, then, represent the Klan. ${ }^{22}$

The issue here is whether Griffin violated racial loyalty norms. The answer is yes. Some might contend that Griffin was merely doing a lawyer's work, defending the unpopular because there are higher principles at stake. Griffin himself said "we can never take the position that the Constitution does not apply to our enemies." But in the cause for racial solidarity, attorneys cannot be granted special rights. Group rules must meet expectations of fairness. There cannot be exclusive privileges for certain vocations or the enterprise will seem inequitable and consequently falter. For example, a black architect who willfully designs the Klan's new headquarters would quite rightly be bloodied by all of the cutting remarks he would receive. Attorneys are trained to consider constitutional rights as of higher importance but non-attorneys are unlikely to rally behind a black person, in any circumstance, working for an avowed racist, particularly when there are plenty of non-black attorneys available. ${ }^{23}$

There is, though, a caveat. If the legal principle in question is important to the black community's goals, then the black attorney's actions are excusable. The reasoning behind this caveat is that in helping white supremacists the black attorney is also helping blacks. Here, Texas was demanding KKK membership lists. This case mimics NAACP v. Alabama (1958) where the Supreme Court held that the NAACP's First Amendment right to privacy outweighed the state's interest in obtaining the association's membership lists. ${ }^{24}$ In $N A A C P$, the organization feared releasing membership lists because its affiliates were often harassed and fired from their jobs in order to terrorize them away from racially uplifting activities. A black attorney who chose to represent the KKK in those years had a viable defense; if the KKK did not have to divulge its membership lists then neither did the NAACP. But today, there is no threat of black organizations being forced to divulge membership lists. Thus this is no longer a viable defense, though it was in the Jim Crow Era. Here, every scenar-

22. Richard Delgado, Yes: More Than Speech Was at Stake, 79 American Bar Association Journal 32 (1993); Sam Howe Verhovek, A Klansman's Black Lawyer, and a Principle, New York Times, Sep. 10, 1993, at B9.

23. Delida Costin, Anthony P. Griffin, B.U. PUB. INT. L.J. 107, 109 (1994).

24. 357 U.S. 449 (1958). 
io of this sort of norm has definitely not been covered, but I have sketched a skeletal outline to which flesh will be added in the rest of the Article. ${ }^{25}$

\section{Inexcusable Meekness}

The second type of racial loyalty norm, which is less complicated than the first, sanctions blacks for inexcusable meekness in the face of racism. Two words are crucial here: "inexcusable" and "meekness." Starting first with meekness, here I mean docile and submissive. A black law professor who, for example, says nothing when the law school's faculty passes over qualified black faculty candidates for clearly pretextual reasons is being meek. Or take a black public intellectual who is too afraid to denounce a politician's racist utterance. Such actions would signal submissiveness. But context matters. By inexcusable, I intend to limit the scenarios where meekness should warrant criticism. A person cannot be expected to extend themselves when there are important competing interests or considerations at play. Recalling the black law professor who voices no opposition to blatant employment discrimination. What if the professor is untenured and fears that vocal agitation might be a career ending response? Or if a black person witnesses a violent hate crime by the local Klan and refuses to testify out of fear? While those acts seem submissive, there are extenuating circumstances that render denunciation improper. Blacks cannot be forced to jeopardize their careers or their lives in order to prove fidelity.

The power of racial loyalty norms is that they further the cause of racial solidarity, which is crucial in securing legal goals and affecting larger public policy debates. The race has an enormous interest in ensuring that no one submits to racism because a docile subordinate people will remain subordinate. As Michael Klarman writes, "[o]ne precondition for eventually overthrowing white supremacy was empowering southern blacks to overcome the norms of deference and subordination that many had internalized in self-defense." Blacks had to, and still have to, boldly confront their oppression in order to create a better existence. ${ }^{26}$

\section{Doesn't Care About Black People}

The last constructive racial loyalty norm penalizes blacks for not caring about the black race. The basic premise here is that blacks who are disinterested in the race's overall condition should be called to account for that disinterest. Caring about the race, after all, is a precondition to embracing black soli-

25. Ibid; 357 U.S. 449 (1958); Yale Rosenberg \& Irene Merker Rosenberg, No: Civil Liberties Belong to Everyone, 79 American Bar Association Journal 33 (1993); Amitai Etzioni, Social Norms: Internalization, Persuasion and History, 34 Law and Society Review 157, 164 (2000).

26. Michael Klarman, Unfinished Business: Racial Equality in American History 108109 (2007) 
darity. Thus, blacks must monitor behavior that evidences a complete rejection of the notion that blacks should be invested in the group. As an initial matter, I should note that these norms are not mutually exclusive categories. A black attorney, that is, might be willing to work for an anti-black organization in part because of indifference to the black plight.

Punishing those who are disinterested in the group notifies all blacks that they are expected to be invested in the race's well-being. Blacks violating this norm will typically reveal themselves to be uncommitted to the goal of stamping out anti-black racism. Some might wonder how one can ever determine "racial apathy." More specifically, what evidence can establish this cultural infraction? Policy positions are helpful only in blatant scenarios. Championing, say, segregation by itself proves treachery. But very few would endorse such obviously repugnant policies now. Any evidence that would persuade a jury that the accused is unconcerned about blacks is acceptable. The most convincing evidence might establish that: a black person's sole claim to fame is lambasting other blacks; close associations and/or defending well-known racists; intellectual inconsistency and/or dishonest arguments that appear more pretextual than sincere. All of these would suggest racial desertion.

Most often, the evidence would be circumstantial not direct. This endeavor, therefore, will require proving a state of mind, an "elusive" pursuit. The secret diary of a politician containing admissions of racial self-hate will not be unearthed. In determining racial betrayal, therefore, the evidentiary burden must be relaxed for there are various ways the supposed betrayer can hide his offenses. A lesser standard that relies on circumstantial evidence is optimal. The need to punish betrayers should and can be balanced by the hesitance in wrongfully banishing a race member. Accordingly, by a preponderance of evidence is the best standard. If after weighing available evidence, a black person concludes that it is more likely than not that the accused does not care about the group, then sanction is permissible. Blacks are fully capable of examining the public utterances and actions of a person to determine if a particular person cares about the race or not. Those uncommitted blacks can indeed be spotted.

\section{B. Destructive Norms}

\section{Unsuccessful Prosecution}

Destructive racial loyalty norms actually encompass three distinct ideas. The first is that a destructive racial loyalty norm more accurately refers to an unsuccessful prosecution of a constructive racial loyalty norm. It is destructive, for instance, to indict someone for furthering the enemy's interest when the asserted enemy is actually no foe at all. Similarly, it is destructive to charge someone with being inexcusably meek without enough supporting evidence. And it is destructive to lambaste someone for not caring about the race when 
the person has a history of being an ardent champion for his people. These are all instances of destructive racial loyalty norms.

The second idea behind destructive racial loyalty norms is that they are sometimes not technically norms. Norms have widespread legitimacy in the population which they operate. Indeed, "the very existence of a social norm depends on a sufficient number of people believing that it exists and pertains to a given type of situation, and expecting that enough other people are following it in those kinds of situations." ${ }^{27}$ Nearly all blacks, for example, agree that blacks should never intend to help the race's enemies. Large percentages of blacks would agree that blacks who are inexcusably meek in the face of racism should be showered upon with criticism. Last, few blacks would take issue with a black person being harshly criticized after he publically announces that he is apathetic about the race's plight. The three constructive racial loyalty norms are all norms within the black community; all black people understand these to be cultural rules that carry significant punishment if broken. But some destructive racial loyalty norms are not so widely appreciated. Boxer Beau Jack, for instance, was criticized in the 1940s for not being able to speak English properly. Being well-spoken has never been tied to racial kinship and is not a norm in the technical sense, at least not a norm associated with racial loyalty. This is an example of a destructive racial loyalty norm because it is an idea that someone wanted to reach norm status and it negatively affected the cause of racial solidarity.

\section{The Bad Norm}

The third idea behind destructive racial loyalty norms refers to a norm that the black community truly understands to be a norm, or at least a strong case can be made that it is a norm. But this norm inhibits the cause of racial solidarity. Take affirmative action for example. Supporting affirmative action very well might be a social norm among blacks. But it is destructive largely because racial solidarity must not mean racial consensus. More pointedly, disagreeing with affirmative action should not be deemed inherently treacherous. The black community should reject these sorts of norms because they are counterproductive; they frustrate the ability to organize racial solidarity. ${ }^{28}$

27. Bicchieri, The Grammar of Society at 2.

28. One obvious issue here is what sort of evaluative methods are being employed here. That is, how can one determine who is guilty of racial treachery? And, more specifically, what values should be used? For instance, is it permissible to use twenty-first century conceptions of submissiveness and require that blacks living a century ago meet those standards? This might be particularly problematic because blacks living in the early twentieth century lived under the very real threat of physical danger. Some might argue that it would be inappropriate to judge racial treachery by current conceptions in such circumstances. It is improper, however, to evaluate past generations on their own social standards when later generations have revealed their predecessors to be undeniably wrong. Take slavery for instance. It would be imprudent to exonerate former slave-owners by pointing out that bondage was once accepted. In this book, I am determining 


\section{THE UNCLE TOM COPS OF THE '60S AND ‘70s}

About the criminal justice system regarding blacks, W.E.B. Du Bois remarked:

The laws are made by men who have little interest in him; they are executed by men who have absolutely no motive for treating the black people with courtesy or consideration; and finally, the accused law-breaker is tried, not by his peers, but too often by men who would rather punish ten innocent Negroes than let one guilty one escape. ${ }^{29}$

In 1969 Louis L. Knowles and Kenneth Prewitt perfectly stated the problem with the criminal justice system in the eyes of many blacks. ${ }^{30}$ "To [black] citizens," they wrote, "the law symbolizes white oppression. Those who represent the legal system are almost exclusively white and reflect the prejudices and ignorance of white society." 31 "The very structures of the system," they continued, "because they are created by whites, invariably operate to disadvantage the culturally different, regardless of who is in control." ${ }^{, 32}$ The Swedish Sociologist Gunnar Myrdal reported after his tour of the segregated South that "the Negro's most important public contact is with the policeman. He is the personification of white authority in the Negro community." ${ }^{33}$ The police officer's chief function regarding race was to "keep the Negro in his place." ${ }^{34}$ The white officer - the first line of defense-was integral in preserving white supremacy. $^{35}$

For much of American history, blacks were routinely portrayed as enemies of the state. The silent film Birth of a Nation promulgated the most deplorable such portrayal, depicting free blacks as naturally violent brutes. That image, though it has grown fainter with time, animated harsh practices of law enforcement against black people. When blacks were lynched, furthermore,

whether the actions in question would hinder efforts to build solidarity among blacks. Even if shameful obsequiousness were more tolerable formerly, that must not inoculate anyone from criticism. But, the facts of a particular era must be part of the calculation. Thus, submissiveness might mean something different in an area where lynching was an ever-present danger.

29. W.E.B. Du Bois, THE SOUls OF BLACK FolK: EsSAYS AND SKETCHES 176 (1903).

30. Louis L. Knowles \& Kenneth Prewitt, Racism in the Administration of Justice, in RACE CRIME AND JustiCE 13 (Charles E. Reasons \& Jack L. Kuykendall eds., 1972).

31. Id.

32. Id.

33. 2 GunNAR Myrdal, AN AMERICAN DILEMMA: THE NEGRO PROBLEM AND MODERN DEMOCRACY 535 (7th prtg. 2009).

34. Homer Hawkins and Richard Thomas are decidedly more vivid. They write, "In every major city where blacks lived in large enough numbers to be noticed and feared by whites, the white police-force was allowed and often encouraged to keep "the niggers in their place."' Homer Hawkins \& Richard Thomas, White Policing Black Populations: A History of Race and Social Control in America, in OUT OF ORDER?: POLICING BLACK PEOPLE 65 (Ellis Cashmore \& Eugene McLaughlin eds., 1991).

35. MYRDAL, supra note 75, at 535-542. 
police departments were often nowhere to be found. ${ }^{36}$ And black criminal defendants were generally denied the constitutional protections that white defendants took for granted. ${ }^{37}$ Blacks, therefore, developed negative associations with the criminal justice system, and its police officers. ${ }^{38}$ Despite significant progress, skepticism remains. ${ }^{39}$ In the 1960 s and the 1970 s, that suspicion was more ubiquitous.

During the 1960s, though, police departments began hiring blacks. This was in response to increasing crime in black neighborhoods, urban riots and because black cops were thought likely to be sympathetic to fellow blacks and therefore better able to police black neighborhoods. Police departments, furthermore began diversifying their ranks to answer civil rights organizations' demands. ${ }^{40}$ Yet in 1971, the New York Times reported that cities had failed miserably at recruitment. ${ }^{41}$ Only Washington D.C. had meaningfully integrated its police force. ${ }^{42}$ But that integration was hollow. Indeed, according to a 1970s study of black cops in the nation's capital, black officers rarely socialized with their white peers, and, as a result of their experiences, two-thirds trusted few or no white officers. ${ }^{43}$ Discrimination around the country was rampant of course, and those few blacks hired were confined by a glass ceiling on which their white peers walked. But one paramount recruitment problem was the low opinion blacks held of police officers. ${ }^{44}$ A black Indianapolis man, for example, declined to join the force because "the image is too bad" and his friends would tease him. ${ }^{45}$ Considering their history with police, many blacks

36. Even when the police stepped in to stop a lynching, "All too often a lynching prevented by the police merely presaged a legal lynching by a kangaroo court. Blacks thus faced a double bind: while weak legal institutions failed to protect them against lynching, strict and "efficient' law enforcement hit them harder than any other racial or ethnic group." MANFRED BERG, POPULAR JUSTICE: A HISTORY OF LYNCHING IN AMERICA 164 (2011). There have been numerous books written about lynching. See William Fitzhugh Brundage, LYNCHING IN THE NEW SOUTH: GEORGIA AND VIRGINIA, 1880-1930; JAMES H. MADISON, A LYNCHING IN THE HEARTLAND: RACE AND MEMORY IN AMERICA (2003); KEN GONZALES-DAY, LYNCHING IN THE WEST, 1850-1935 (2006); AMY Louise WoOd, LYNCHING and SPECTACLE: WitNESSING RACIAL VIOLENCE IN AMERICA (2009).

37. One of the main constitutional protections denied to blacks was a criminal trial where members of their race were not purposefully excluded from the jury. See generally Brando Simeo Starkey, Criminal Procedure, Jury Discrimination \& the Pre-Davis Intent Doctrine: The Seeds of a Weak Equal Protection Clause, 38 Am. J. Crim. L. 1 (2011).

38. See Ann Martin, The Police and the Black Community, 3 J. Police L.Q. 22 (1974).

39. MANFRED WEIDHORN, AN ANATOMY OF SKEPTICISM 106 (2006).

40. John L. CoOper, The Police AND the Ghetto 116-117 (1980); Paul Delaney, Recruiting of Negro Police is a Failure in Most Cities, N. Y. TIMES, Jan. 25, 1971, at 1. Cooper writes, perhaps some disagree, that history does not validate the prediction that black cops would be more sympathetic to blacks. COOPER, supra note 40, at 117.

41. Delaney, supra note 27 , at 1 .

42. Id.

43. Kenneth Bolton Jr. \& Joe R. Feagin, Black in Blue: African-American POLICE OFFICERS AND RACISM 121 (2004).

44. See Delaney, supra note 27 , at 1.

45. Id. 
looked suspiciously at their brethren who opted to become cops. To them, a person voluntarily immersing themselves in an environment the race identified with bigotry was puzzling. The racial loyalty of anyone who dared become a police officer was indeed in question. Blacks who cashed checks that police departments drafted were vulnerable to paying a stiff price: Uncle Tom.

Being a police officer is inherently dangerous. Each night, an officer's family wonders if their loved one will return home. But for the black officer the consternation was amplified. The black officer, at least in the 1960s was "much more than a Negro to his ethnic group because he represents the guardian of white society, yet he is not quite a policeman to his working companions because he is stereotyped as a member of an 'inferior' racial category." 46 Blacks had difficulty defending their decision to become police officers because they accepted a position long-identified with white supremacy and often viewed as an enforcer of the racial hierarchy. ${ }^{47}$ Norman Randall, a Maryland police officer, said it well in 1962 when he declared, "If you were black and you joined the white establishment, you were an Uncle Tom."48 A decade later, the idea that black cops were susceptible to Uncle Tom accusations persisted. Officer John W. Littles, from Washington D.C., disclosed in 1972 that he was often derided as an Uncle Tom, a "White Man's Nigger," and "Oreo."49 This was the life of the black police officer.

As Randall's and Littles's testimony demonstrates, black cops were viewed suspiciously. The race likely feared that blacks would forget their roots if they became police officers. No true "race man," according to this reasoning, would become a policeman. Thus, a black cop was assumed to be an Uncle Tom. The black cop was supposed to change the character of law enforcement. It was frequently believed, however, that he was nothing more than a white cop inside a black shell. This dynamic is evident upon investigating the seeming inconsistency of blacks insisting that police departments hire more black officers but then criticizing those very same officers as Uncle Toms.

In the 1960s and 1970s, violent crime, especially in black neighborhoods, grew alarmingly high. ${ }^{50}$ Many contended that it was difficult for whites to police black areas because of ingrained distrust. ${ }^{51}$ Departments across the country concluded that black cops could better police those communities. ${ }^{52}$ Recruiters,

\footnotetext{
46. Nicholas Alex, Black in Blue: A Study of the Negro Policeman 13-14 (1969).

47. Id. at 32 .

48. Anne Arundel, City Honors Its First Black Police Officers, Integration Came 40 Years Ago, WASH. POST, Dec. 14, 2000, at M03.

49. Ron Shaffer, Compassion Wins Honor for Officer, WASH. POST, Aug. 20, 1972, at

B1.

50. Carl Husemoller Nightingale, On the Edge: A History of Poor Black CHILDREN AND THEIR AMERICAN DREAMS 4 (1993).

51. ALEX, supra note 91 at 28.

52. Id.
} 
then, toured black colleges, advertised in black newspapers, and visited black churches in search of potential candidates. ${ }^{53}$ The Washington D.C. police department even sent a "recruitmobile" to black slums. ${ }^{54}$

Departments were stunned, however, that, when venturing into black neighborhoods, black cops were denounced as "Uncle Toms.,"55 "The negro citizenry," proclaimed one white Los Angeles police officer "was crying for the department to add more Negro policemen. ${ }^{56}$ Then when we send Negro officers out into areas where mostly Negroes live, these Negro officers are openly called all kinds of names and instantly become objects of thrown trash, bricks and bottles." 57 Sacramento Sheriff John Misterly similarly relayed that blacks desired inclusion. ${ }^{58}$ "But," said Misterly, "we have very few black applicants per year, probably because they feel they will be labeled 'Uncle Tom's' if they enter police work." 59 Misterly's hunch, that blacks feared the Uncle Tom label, was correct. As one black student said in 1970, "Black policemen can't do much because of the way the system is. Blacks call them 'uncle toms.' I wouldn't become one." 60 Blacks in Los Angeles were so wary of the LAPD that it struggled to hire local blacks. ${ }^{61}$ So few, in fact, wanted to be associated with it, that the LAPD was compelled to leave the state and recruit at southern universities. ${ }^{62}$

But cynicism should have been expected. Los Angeles Sentinel columnist Bill Lane faulted the white power structure. ${ }^{63}$ "[I]t all points up a display of harvest now being reaped from a crop of racial Jim Crow sown over the past 30 years in police departments," Lane wrote in the black newspaper. ${ }^{64}$ His critique concerned Los Angeles, but applied broadly. Employment discrimination within police departments denied entrance to but a handful of blacks. There was, therefore, an unmistakable stench of racism emanating from law enforcement officials. Black cops had to accept odious bigotry, many blacks presumed, in order to remain on a police force. Many apparently believed that a black officer who endeavored to sanitize the department and purge prejudiced elements would face a quick dismissal. ${ }^{65}$ The true race man, in other words, would never survive but the accommodating one would. Perhaps this explains why when

53. Id.

54. Id.

55. Bill Lane, The Inside Story, L.A. SEnTINEL, May 12, 1966, at D2.

56. Id.

57. Id.

58. Sheriff Says Recruiting Snag on Written Tests, SACRAMENTo ObSERVER, Jan. 29, 1970 , at B31.

59. Id.

60. Roving Reporter: What People Think, SUn REPORTER, Sept. 26, 1970, at 14.

61. Id.

62. Id.

63. Lane, supra note 55, at D2.

64. Id.

65. See id. 
Winston Moore, superintendent of the Cook County Jail, became the first black head of a major penal institution in 1968 he declared that "I am not an Uncle Tom. I have never been one and will never be one." ${ }^{66}$

This might spur belief in the existence of a social norm that black cops were inherently Uncle Toms. But such a reading is wrong. Black cops, rather, were sometimes deemed Uncle Toms because negative traits were inferred. Black officers, that is, were sometimes considered Uncle Toms not because they were cops but because many assumed that black cops would invariably develop the repugnant characteristics identified with duplicity.

The account of Bob Oliver, who shed the Uncle Tom label, supports the contention that blacks were not deemed Uncle Toms simply because of their vocation. Oliver, also a first-baseman for the Anaheim Angles, was a part-time officer in the 1970s. "I wasn't accepted too well at first," Oliver recounted. "I was just another black pig. An Uncle Tom. But the kids saw I was a good guy and started gaining confidence in me." ${ }^{67}$ If being a black cop inherently violated a social norm, Oliver could not redeem himself through good deeds. The Sentinel's explanation of why young blacks refused to become cops also buttresses this point. "[T] date," the newspaper wrote "perhaps the major reason most young men from this community shun the blue uniform is because they have been led to believe that the police department is a racist group and there is no future for a black man in the department unless he takes on the garments [sic] of an 'Uncle Tom.' This he refuses to do." ${ }^{68}$ Black cops were deemed Uncle Toms - which evidenced that they broke a social norm - not generally for their status, but because the community expected treasonous inclinations from them.

A black officer named Derek Ackeridge endeavored to explain that not all black cops were Uncle Toms. ${ }^{69}$ Ackeridge understood blacks' hostility towards the police and black officers specifically. ${ }^{70}$ Police departments, he posited, symbolized oppression. ${ }^{71}$ But Ackeridge contended that some black cops were worthy of adulation, holding that there was a difference between the black cop and the Uncle Tom cop. ${ }^{72}$ The black cop, on the one hand, genuinely was devoted to his people. The Uncle Tom cop, on the other hand, was self-interested, an enemy to the black cop and the entire black community. "The Uncle Tom cops," Ackeridge indicated, "shun [the black cop] out of fear that he might

66. 'I'm No Uncle Tom' Says New Jail Boss in Chicago, New J. \& GuIDE, Mar. 23, 1968 , at 8 .

67. Dave Distel, This Is Interesting Work, L. A. TIMES, Feb. 12, 1974, at C1.

68. Where Are Black Officers?, L.A. SENTINEL, June 10, 1971, at A6.

69. Patrolman Derek T. Ackeridge, The Policeman A Black Nationalist, N. Y. AMSTERDAM NEWS, July 31, 1971, at A7.

70. Id.

71. Id.

72. Id.

73. $I d$. 
make waves in the police department standing up for justice and ... in so doing create[s] problems for them. These Uncle Toms, to achieve their status, had to disregard their manhood to become boot licking lackies [sic] for the bosses. They tap danced while the boss was whistling Dixie just to become head nigger in charge." ${ }^{74}$ Ackeridge's maligning black cops for kowtowing to white bigotry for their own self-interests was constructive. Black officers who acquiesced to bigotry not out of fear for their own occupational future, but as a strategy to further their own career, has shown themselves to lack any concern for the race.

Ackeridge touched upon the salient issue animating social norm management of black police officers. Many blacks, including Ackeridge, believed there was a social climate within police departments that promoted conduct and attitudes that would render black cops unwilling or unable to push for positive change in the criminal justice system. Within police departments, many presumed, blacks were pressured to comport subserviently, avert their eyes to injustice, or worse, actively perpetrate abuse on blacks. And blacks' fear was justified because[i]n the process of adaptation, many black officers conform to the informal norms of police departments. ${ }^{75}$ Indeed, "[t]heir lower occupational status, coupled with a desire to maintain a positive self-image as a good professional officer, can lead . . to . . . conforming." ${ }^{, 76}$ Many black cops, in other words, refused to buck the system and instead became police officers who perpetrated injustices on fellow blacks. A segment of the black community countered by pressing black cops to neither debase themselves nor further their career at the expense of the well-being of black America. Blacks needed a counterbalance to compete with the pressure black cops faced within police departments. The answer was enforcing the norm that black cops must neither exhibit servility nor abuse other blacks. Norm breakers were punished with Uncle Tom denunciations.

Concluding that an officer is guilty of betrayal without individualized evidence is quite unfair. But alerting black cops, who were put in situations where eschewing racial solidarity was likely very tantalizing, that treachery would be penalized was constructive because it encouraged black officers to think in racial solidaristic terms. They were members of a racial group that was treated poorly by the criminal justice system of which they were also member. This racial loyalty enforcement could coax blacks into seeing themselves as engines of reform that could reshape the criminal justice system, rendering it fairer. Such norm management could, furthermore, compel black cops to respect the black citizenry and treat them with dignity, a different tact than what many white cops chose.

74. Id.

75. Boltin \& Feagin, Black in Blue: African-American Police Officers AND RACISM 121 (2004).

76. Id. John Cooper writes that black officers were "informally. . discouraged from being too helpful or friendly with residents of the ghetto." COOPER, supra note 85, at 117. 
This use of Uncle Tom, in fact, fit all three categories of constructive racial loyalty norms. First, signaling to black officers that their behavior was being monitored could dissuade black officers from furthering the interests of the race's enemies. If blacks correctly believed that police departments enforced racial subordination, then notifying blacks that ostracism was a penalty for complicity was wise; it lessened the likelihood that black officers would emulate their worst white peers.

Second, such norm management punished inexcusable meekness. Blacks cannot be permitted to perpetrate racism against fellow blacks because they want their conduct to match that of their white coworkers. Blacks, moreover, had to prevent black cops from wilting under the intense pressure to ignore discriminatory practices that many police departments likely applied. Deploying Uncle Tom in this fashion, in fact, could have encouraged blacks to endeavor to reform police departments from within. If blacks' regulating racial fidelity could incite black officers into aspiring to correct the wide-ranging problems endemic in many police departments, then it was a worthwhile undertaking.

And third, this use of Uncle Tom could galvanize black officers to be interested in the race's well-being. Ensuring that black cops appreciated that they should be invested in the status of the group less they be publically branded as turncoats could compel them into behaving in ways that would accrue to the benefit of the larger black community.

Perhaps because they feared group ostracism-suggesting the power of Uncle Tom and social norms - some black officers refused to remain quiet amid the racial hostility and inequality of 1960 s police department. Many black cops felt they were treated differently than their white peers. ${ }^{77}$ Black officers contended that employment standards were higher for them in terms of hiring, retention and promotion. ${ }^{78}$ Oftentimes blacks were only permitted to police black neighborhoods and could only occupy low-level positions. ${ }^{79}$ Studying the data, Nicholas Alex concluded that the black officer "is far from achieving the full status that the job implies for his white counterpart."

Melvin Jackson, a black Philadelphia policeman, harbored such grievances. ${ }^{81}$ Jackson's insider status, as true with Ackeridge, provides a unique position from which to study the behavioral regulation of black cops. Jackson resigned in 1967, after a fifteen month stint. ${ }^{82}$ There was rampant discrimination in the force, Jackson disclosed, claiming that blacks were continuously passed

77. ALEX, supra note 46, at 112

78. Id.

79. Id.

80. Id.

1.

81. Len Lear, Quits Police Force; Charges Harassment, PHILA. TRIB., Nov. 28, 1967, at

82. Id. 
over for promotions in favor of whites with less seniority. ${ }^{83}$ Blacks, moreover, were confined to the lowest duties, he insisted. ${ }^{84}$ "This is the way it is throughout the whole police department," he claimed. ${ }^{85}$ "You have to be an Uncle Tom to get ahead. If you 'make waves' or 'create problems' they discipline blacks." ${ }^{, 86}$ Jackson, in other words, punished blacks who acquiesced to the racism within police departments as Uncle Toms. Such comments notified black police officers that accommodation was frowned upon in the black community.

His criticism, however, was only constructive if the blacks in question consciously strategized to further their own careers by taking on the persona of "the black man who won't complain." As mentioned in Part I, it is not inexcusably meek to remain silent on bigotry within one's professional setting if speaking out will effectively terminate one's employment. But purposefully not speaking on bigotry just to reap personal benefits is a patently obvious disloyal tactic deserving of swift censure.

Jackson's testament further underscores the impetus for creating social norms to regulate the behavior of black cops. The system rewarded black cops who avoided challenging the status quo. The self-interested black officers, therefore, realized the personal benefits to be acquired by playing the role of the "compliant Negro." A tactic to dissuade blacks from pursuing that portrayal was announcing that any who accepted the role incurred a heavy penalty. Blacks could not betray the race without retribution. The cost for racial treason had to be high. Raising the price of racial duplicity was the function of racial loyalty norms and Uncle Tom.

The behaviors that Jackson reported appear mild in comparison to other findings. Take the events of a black family in the Northeast into consideration. A mother of four, Mrs. Anna Hill was beaten by white thugs in her predominantly white neighborhood just a week after the family moved into their new home. $^{87}$ On a July afternoon in 1970, Mrs. Hill sent her 14-year-old son and her 13-year-old daughter to a local store. ${ }^{88}$ On their trip, white youths hurled bottles at the siblings and sexually threatened Hill's daughter. "We're going to get some nigger," they shouted. ${ }^{90}$ Mrs. Hill approached white women nearby to discuss the incident. ${ }^{91}$ The women, unwilling to converse, handed bats to two nearby white boys who then proceeded to bludgeon Hill. ${ }^{92}$ She then called

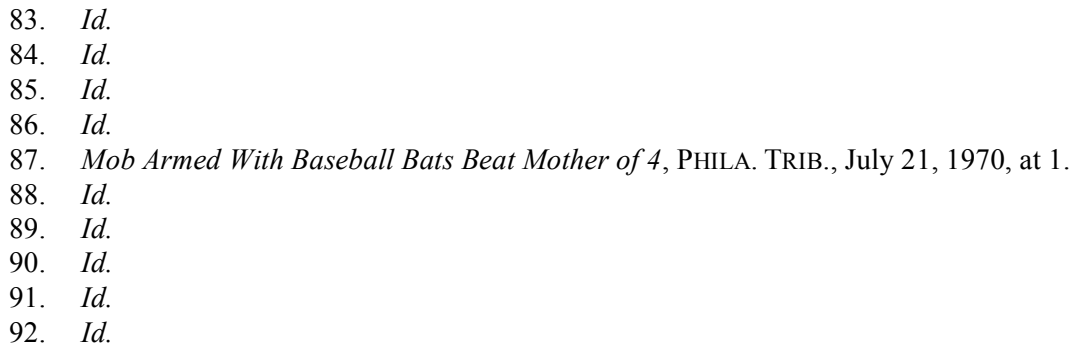


the police. ${ }^{93}$ Two policemen arrived on the scene, one black the other white. ${ }^{94}$ The black police officer told her that he refused to intervene. ${ }^{95}$ Later when discussing the unfortunate events, Mrs. Hill said, "That [U]ncle Tom told me that 'this is a white neighborhood and that he couldn't protect a few of us blacks." "96 Hill's use of Uncle Tom here was constructive. A black police officer expressing his unwillingness to do his job on behalf of blacks has clearly violated the racial loyalty norm that proscribes behavior evidencing a lack of concern for the group.

Perhaps on par with the previous supposed Uncle Tom cop was an officer Charles Evers ${ }^{97}$ recalled in his autobiography. ${ }^{98}$ Evers's awareness of "Tom," as he labeled him, began after Evers helped launch an economic boycott in Port Gibson, Mississippi. ${ }^{99}$ The boycott immensely successful, resulting in blacks being hired in stores, two black police officer placements in addition to one deputy sheriff appointment. The city also agreed to take accounts of police brutality seriously as well as an agreement to cease referring to adult blacks as "boys" and "girls."100 Emboldened by their victory, blacks next agitated for better schools, streets and sewers. ${ }^{101}$ But the more blacks pushed the more the whites invigorated their defense of the status quo. Desiring to maintain the integrity of their prized racial caste, city bigwigs hired a white police chief, an assistant police chief with a reputation of being abusive to blacks and Tom, the black policeman. ${ }^{102}$ His assignment was to spy on and intimidate blacks. ${ }^{103}$

Tom, an obvious derivative of Uncle Tom, was a natural target of derision. By willingly serving as a sleuth for whites attempting to stunt racial progress, Tom revealed himself as amendable to throwing the race overboard as he navigated a self-serving strategy.

Tom, in short, violated the norm that requires blacks to care about the race and also the norm that prohibits furthering the enemies' interests. Blacks needed to crack down on those hiding behind their police shield to serve as a saboteur because doing so helped forge racial solidarity that could serve as a launching pad for implementing strategies for full racial emancipation. Tom was unlikely to be brought back into the fold after being branded a race traitor. If others, though, knew about the censure he received, they would be less likely

93. Mob Armed With Baseball Bats Beat Mother of 4, PHILA. TRIB., July 21, 1970, at 1.

94. Id.

95. Id.

96. Id.

97. Charles Evers is the brother of Medgar Evers, the civil rights worker slain in Mississippi. See generally Myrlie Evers-Williams \& Manning Marable, The Autobiography OF MEDGAR EVERS: A HERO's LIFE AND LEGACY (2006).

98. CHARlES EVERS, EVERS 176 (1971).

99. Id.

100. $I d$.

101. Id

102. Id. at $176-77$.

103. Id. at 177 . 
to follow his path, resulting in a population that contained less betrayal and more unity.

Many might find the behavior of Captain Chester Gethers, who was deemed an "Uncle Tom" cop in June of 1965, less troubling. ${ }^{104}$ Gethers, a Philadelphia police officer, ordered the arrest of two black demonstrators at Girard College who were supposedly blocking street traffic and disturbing the public while participating in a political protest. ${ }^{105}$ Cecil B. Moore, head of the local chapter of the NAACP, claimed that Gethers failed to first ask the two gentlemen to move. ${ }^{106}$ During a later protest, Moore denounced Gethers as an "Uncle Tom in charge of that West Philadelphia cotton patch." 107 Moore pushed the protestors to picket Gethers's police station and even his home to "let his children see what kind of Uncle Tom they have for a father."108

It seems as though Gethers could have avoided ostracism if he simply warned the protestors instead of quickly arresting them. Working against him was that he easily could be viewed as the black marionette cop who hindered a civil rights protest at the behest of his white bosses pulling his string. It is unknowable whether Gethers attempted to curry favor with whites by showing that he too could be tough on the "unruly blacks," rendering it difficult to appraise the constructiveness of the use of Uncle Tom here. But given the circumstances, some blacks were predisposed to opt negatively interpreting his actions.. Gethers, therefore, became an archetype of the black cop who sacrificed the race's interests for his own.

What was true for officer Gethers was common throughout the era-a segment of the black population sought to foster group unity to improve their condition. The black cop, as a component of an unequal criminal justice system, faced perhaps added burden to be an agent of change. Any hint of failure resulted in group ostracism. But the norm management of this era was quite constructive. Blacks used Uncle Tom and enforce racial loyalty norms in ways that promoted racial solidarity that provided a starting point to contest inequities and mobilize blacks around important legal interests.

\section{POST-1975: UNCLE TOM AND THE UNEQUAL JUSTICE SYSTEM}

From 1960 to 1975 , the behaviors monitored within the context of the criminal justice system were that of the black officer. In the criminal justice system, blacks during those years could consistently only be spotted as cops. There was a dearth of black cops to be sure, but compared to, say, the judiciary,

104. Art Peters, Official Vows 'Won't Take It Lying Down', PHILA. TRIB., June 8, 1965, at

1.

105. Id.

106. Id.

107. Id.

108. Id. 
police forces were beacons of inclusion. The overwhelming majority of blacks working in the justice system positioned to be called Uncle Toms, therefore, wore police uniforms.

As a product of the successes of the Civil Rights Movement, employment opportunities expanded, including increased representation and power within the justice system. When it came to cops, for instance, "concerns for the prevention of civil disorders and for equal employment opportunity after 1970 led to a marked increase in the number of blacks in sworn ranks in some departments, [although] other departments showed little change."109 And in cities with black mayors, black police chiefs or local governments that practiced affirmative action, the numbers of black police officers increased. ${ }^{110}$ Black prosecutors and judges are certainly rarer than black cops in the criminal justice system. Even still, however, there is a drastic difference from just two decades ago. ${ }^{111}$ But as sectors of law enforcement diversified these new entrants became exposed. A segment of the black population, as true previously, still endeavored to maintain intra-racial discipline through the racial loyalty norm management. The impetus for this behavioral regulation remained the desire for racial unity to organize against perceived legal injustice and general racial inequality. Blacks still interested in moderating black behavior, though, ceased to be solely concerned with simply ensuring that blacks within the criminal justice system were not merely black versions of bigoted white actors. Blacks, instead, frequently managed more onerous and destructive norms. Following Uncle Tom, a frequent punishment for violating these norms, facilitates the recognition of how they were developed, spread and enforced.

\section{A. Brutality and Racial Loyalty}

Some norm management, though, remained constructive. And we see such a rare example in the early 1990s. Then, a white man named Jody Atkins murdered Terrell Royce Rutledge, black, in Cross City, Florida in $1992 .{ }^{112}$ According to the state, Atkins visited the black side of town to buy crack cocaine. ${ }^{113}$ After leaving, Atkins realized that he had been duped and given soap instead of drugs. ${ }^{114}$ Atkins, then, returned and demanded his money back. ${ }^{115}$ A scuffle ensued. ${ }^{116}$ One of Atkins's foes struck his truck with an axe and Atkins responded by shooting and killing Rutledge, an innocent bystander, with a

109. JAYNES \& WILLIAMS, A COMMON DESTINY: BLACKS AND AMERICAN SOCIETY 490 (1989).

110. Id. at 491 .

111. Id.

112. Mike Clary, Deep South, Deep Trouble, L. A. TIMES, Jun. 17, 1992, at E1.

113. Id. at E7.

114. Id.

115. Id.

116. Id. 
semi-automatic rifle. ${ }^{117}$ "All I was doing," Atkins boldly confessed later, "was trying to kill me some niggers." charged with third-degree murder because, under Florida law, they committed a felony that played a role in a killing. ${ }^{119}$ Deborah Mitchell, a local black activist, in response, conducted a one woman crusade on behalf of the so-called Cross City Five. ${ }^{120}$ Mitchell received no assistance from other blacks because, she claimed, they were too timid to confront whites. ${ }^{121}$ The city's black chief, Marcellus Dawson, was in Mitchell's crosshairs and she distributed literature accusing him of being an "Uncle Tom" and a "traitor" who "terrorize[ed] the black community with threats of imprisonment" ostensibly if they made too much noise in the wake of this incident. ${ }^{122}$ Blacks thought there was a racist conspiracy afoot and that Chief Dawson ${ }^{123}$ was its Uncle Tom muscle. If Mitchell was correct, then Dawson was unquestionably guilty of treachery for cowing blacks into silence.

But not only active abuse was considered a transgression against the race. A bad actor could be denounced as an Uncle Tom by acts of omission. The story of black New York correctional officers who ignored the mistreatment of black inmates illustrates this. David Jemmott, a black correctional officer, witnessed many black inmates being abused in a medium security prison in Sarasota, New York. ${ }^{124}$ Jemmott continuously reported incidents to his superiors. ${ }^{125}$ Other black officers, however, kept quiet and the inmates considered them $\mathrm{Un}$ cle Toms. ${ }^{126}$ A black Washington D.C. resident witnessed similar misdeeds from white cops. ${ }^{127}$ But he "urge[d] Blacks also to look at Black officers who do not speak out about this kind of abuse. They are the Uncle Toms in blue who, like their White counterparts, are not friend[s] of yours." 128

Indicting black insiders for their silence in the face of evidence of brutality against blacks is a thorny proposition. As discussed earlier, some black insiders were reluctant whistleblowers because they consciously adopted a strategy to overlook abuse in order to become one of the well-liked blacks thereby furthering their own careers. Such persons ran afoul of constructive norms.

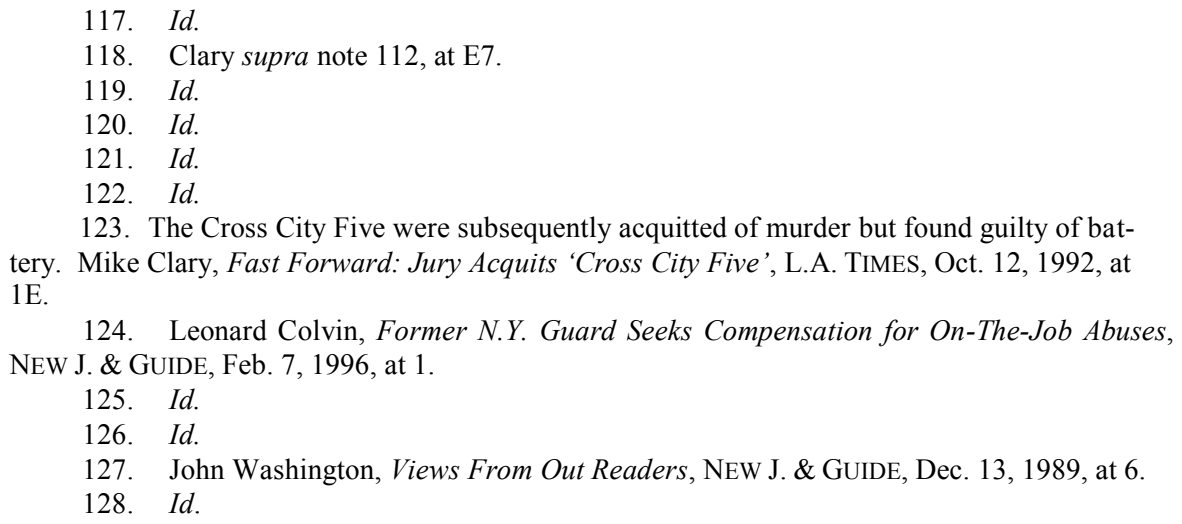


But blacks who did not speak on the evils of abuse of blacks because they feared losing their jobs is a different matter. As mentioned in Part I, social norms cannot be so onerous that it compels blacks to reject the notion of racial loyalty altogether. Requiring blacks to sacrifice their jobs meets that standard. Thus, if the blacks who were silent on abuse did so because their job may have been on the line, they were not guilty of violating any constructive norms. And criticizing them for their silence was quite destructive. The black community, though it has an interest in ensuring that members of the criminal justice system do not brutalize blacks, cannot require that all blacks speak out about it if doing so might result in a loss of employment. Social norms cannot make it so that a paycheck is competing with racial loyalty. The brutality of white cops has even been imputed onto black cops as the case of Rodney King illustrates. On March 3, 1991, Los Angeles officers severely beat King. ${ }^{129}$ The heinous attack was famously caught on camera. ${ }^{130}$ Once the beating was broadcast in a perpetual nationally televised loop, ${ }^{131}$ the city's black cops were routinely derided. Black officers were reminded of their membership in a reputedly racist organization and were painted as traitors. ${ }^{132}$ Officer Garland Hardeman went to a black neighborhood and heard a woman shout, "What are you going to do, beat me like Rodney King? . . Y You black cops are just Uncle Toms. You're no better than the white boys!"133 Hardeman felt "ashamed" and sympathized with the black community because as a black cop, he was "exposed to the same kind of discriminatory treatment they are." $" 134$

The four LAPD officers charged in connection with the Rodney King beating were acquitted ultimately. ${ }^{135}$ "King was interpreted as perpetually threatening to beat the police who beat him," writes Linda Williams. ${ }^{136}$ And "this threat," she continues, "embodied in the sight of the powerful black male body, made his beating defensible in the eyes of both white police and white jurors." ${ }^{137}$ For six days after the verdict, the city was engulfed in the flames,

129. Tracy Wood \& Faye Fiore, Beating Victim Says He Obeyed Police; Law Enforcement: He is Freed from Jail. D. A. Files No Charges Against Him, L.A. TIMES, Mar. 7, 1991, at 1.

130. Id.

131. Robert Deitz, Willful InJustice: A Post-O.J. Look at Rodney King, AMERICAN JUSTICE, AND TRIAL BY RACE 189 (1996).

$1 \mathrm{~A}$.

132. See Charisse Jones, Black Cops Caught in the Middle, L.A. TIMES, Apr. 15, 1991, at

133. Id.

134. Id.

135. Richard A. Serrano, All 4 Acquitted in King Beating, L.A. TiMES, Apr. 30, 1992, at 1.

136. Linda Williams, Playing the RaCe Card: Melodramas of Black and WHITE FROM UNCLE TOM TO O.J. SIMPSON 266 (2001).

137. Id. 
destruction and mayhem that are forever linked to the 1992 Los Angeles riots. $^{138}$

Black police officers in the city possibly recall it as a time when they were considered the worst of the worst sellouts. Blacks were outraged at the acquittals and vengeance was leveled at black cops who were a part of the LAPD. One black police officer said that he was called an "Uncle Tom" and a "traitor" while wearing his uniform in his own black neighborhood during the riots. ${ }^{139}$ Another officer was spat upon and yelled at when trying to quell a group of rioters. ${ }^{140}$ "You sell-out! You sell-out! Why are you working for a white man?" one shouted. ${ }^{141}$ The officer's nearby partner was asked, "Whose side are you on?"142 Others called the partner, "Uncle Tom!. . King beater! . . Oreo! . . . We're going to get you!" "143 Black members of the National Guard who were called in to assist were attacked as well. ${ }^{144}$ Guardsman Wade Morris, for example, recounted that he was dismissed as a "Sellout," "Uncle Tom," and "House Negro." 145 Morris, who was trained to fight in war, said that the epithets brought him to tears but he understood the anger behind the slurs. ${ }^{146}$ "In this city," Morris relayed "if a brother just wears baggy pants, he gets searched." 147 "And if five brothers are in a car," he continued "they will be pulled over. It's accepted as a fact of life here for black men. But we still have a job to do and that is to protect innocent people. I can't worry about the other stuff." "148 Even when Willie L. Williams took over as police chief of the LAPD in May of 1992, two black organizations in the city called him an "Uncle Tom" for taking the job. ${ }^{149}$

Some observers might contend that the cops were called Uncle Toms just for being officers. A better reading, however, was that the brutality of the cops in the Rodney King incident was projected onto the black cops in L.A and they were, consequently, Uncle Toms by association. The racial distinctions between the assailants in the King beatings were blurred, and swaths of L.A.'s black community refused to discern black cops as being any different than

138. MARK BALDASSARE, THE Los ANGELES Riots: LesSONS OF THE URBAN FUtURE 136 (1994). C11.

139. Karen M. Thomas, Riots Tore at Black L.A. Cop's Soul, CHI. TRIB., May 9, 1992, at

140. Stephen Braun \& Leslie Berger, Chaos and Frustration at Florence and Normandie, L.A. TIMES, May 15, 1992, at A1.

141. Id.

142. Id.

143. Id.

144. Paul Shepard, Black Guardsmen Put Duty First in L.A., Plain DeAler, Apr. 16, 1993, at 10A.

145. Id.

146. Id.

147. Id.

148. Id. at $1 \mathrm{~A}$.

149. John Brazington, King Case May Go to Federal Court, PHILA. TriB., May 1, 1992, 
those who showered King with blows. If they insisted on remaining in the LAPD, it was as if the city's black officers had participated in the beatings themselves.

But indicting black cops in Los Angeles for racial betrayal simply based on the membership within the LAPD was destructive, as norm management often was during this period. The LAPD very well might have been racist. Black cops, however, were not guilty of racial betrayal simply because they worked for an unjust entity. All successful prosecutions for treachery are based on evidence establishing some behavior that hindered racial progress. That evidence was wanting here. None of the officers, in short, violated constructive racial loyalty norms. In fact, maligning them as Uncle Toms impaired the cause of building racial solidarity. Indeed, if blacks believe they may be branded as traitors for such flimsy reasons, some might reject altogether the cause of joint action. Racial solidarity is a powerful tool for subordinate groups to pull together manpower to improve their lot. Incidents like these underscore the point that while policing loyalty can help build racial solidarity, the cause can be severely hamstrung by ham-handed efforts to manage social norms.

\section{B. Preferential Treatment and Uncle Tom}

In the previous examples blacks working in criminal justice fields in this era were considered Uncle Toms for supposedly treating fellow blacks poorly. But more prevalent was blacks being considered Uncle Toms for failing to provide preferential treatment, or more precisely, for helping produce an outcome that negatively affected a black person. As blacks began occupying positions with power, some blacks defined racial solidarity around the notion that these power holders must exercise their clout to benefit blacks, at all costs. Some, that is, defended the notion - a notion that the defender likely felt should have been a social norm - that blacks should use also their status to generate positive outcomes for other blacks. This was destructive norm management.

In 1982, we see an example of a black judge being called an Uncle Tom almost certainly for this reason. Wayne Williams was convicted of murdering two men in Atlanta and the police uncovered that his spree was far larger. ${ }^{150}$ Williams, in fact, was the infamous Atlanta Child Murderer, killing more than 20 black children, slayings that haunted the city from 1979 to $1981 .{ }^{151}$ The prosecution's circumstantial evidence against Williams was reputedly of "unprecedented strength." 152 This did not, however, foreclose some blacks from fathoming that a racist conspiracy was at work, even though Atlanta's black po(1983).

150. BACM RESEARCH, ATLANTA Child Murders: WAYNe Williams FBI Files 449

151. James Baldwin, The Evidence of Things not Seen 12 (1995). See generally Bernard Headley, The Atlanta Youth Murders And the Politics of RaCe (1998).

152. Art Harris, Atlanta's Doubts, WASH. PosT, Mar. 1, 1982, at A1. 
lice chief apprehended Williams along with a black FBI agent and despite Williams being convicted by a majority black jury before a black judge. ${ }^{153}$ Rev. Joseph Lowery, ${ }^{154}$ an Atlanta civil rights icon, remarked that skepticism was understandable because, "Let's face it, blacks have been victimized by the courts. Blacks are naturally suspicious." 155 Williams's parents contended that their son was innocent. ${ }^{156}$ After the conviction, Williams's father called the white prosecutor a "[s]on of a bitch." black judge and said her son was convicted because of a conspiracy between the "conniving prosecutors" and an "Uncle Tom," Judge Clarence Cooper. ${ }^{158}$ It is not known why exactly Williams's mother denounced Judge Cooper as an Uncle Tom. But one cannot help but presume that if her son was found not guilty, Cooper would have been anything but an Uncle Tom in her eyes.

A black state judge handling an obscenity case was called an Uncle Tom because he similarly was considered antagonistic to a black defendant. ${ }^{159}$ In 1989, raunchy rap group 2 Live Crew released their third album, As Nasty As They Wanna Be. ${ }^{160}$ After performing their sexually explicit songs during a Florida concert, they were arrested for obscenity. ${ }^{161}$ The judge told the rap group that they and their music were detestable. ${ }^{162}$ The judge's thoughts were shared by many. San Antonio stores, for example, pulled the record from its shelves. ${ }^{163}$ The solicitor general of South Carolina gave storeowners ten days to remove the album from its shelves. ${ }^{164}$ Forty-nine weeks after the album was released, Florida storeowners who sold the album were arrested. ${ }^{165}$ Luther Campbell, 2 Live Crew's front-man, called the judge an "Uncle Tom" in response. ${ }^{166}$ A black female criticized Campbell and his use of Uncle Tom in a letter to the New York Times. ${ }^{167}$ She argued, convincingly, that Campbell wrongly sought to rally blacks around his cause by playing on their understandable fears of white racism "to protect a right that has nothing to do with race. . . This means that no black person can ever criticize any other black person's

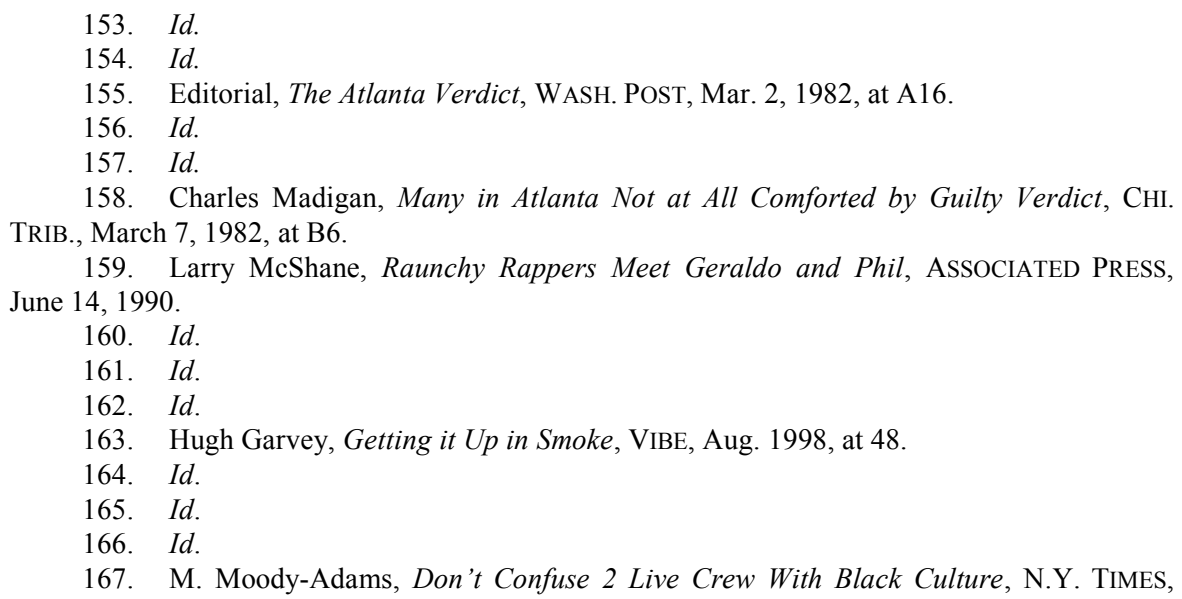


conduct without being called ... an 'Uncle Tom."'168 Because the black jurist violated no constructive norm, Campbell's use of sellout rhetoric was indefensible.

Ohio $v$ Ward, a 1986 criminal law case, compliments the previous precedents of how Uncle Tom is often launched at blacks in the criminal justice system who fail to display sufficient favoritism to other blacks. ${ }^{169}$ The defendant, Brenda Ward, was inside a local supermarket in Dayton. ${ }^{170}$ Ward, though, was not doing much shopping. She, instead, was attempting to steal food. ${ }^{171}$ When she vacated the store with her friend, a cashier noticed "bulges" in their coats. ${ }^{172}$ The security guard followed them, demanding their return. ${ }^{173}$ They ignored the command and fled. ${ }^{174}$ The guard pursued them but only apprehended Ward. ${ }^{175}$ Once Ward was escorted back into the store, the police came and arrested her. ${ }^{176}$ Before she was taken away, she called the guard a "mother fucker, Uncle Tom nigger."177 Ward apparently thought that because the security guard was black he owed allegiance to her, even though she was a thief and his job required him to stop her.

In this next tale, an interesting dilemma presented itself for a black criminal defense attorney representing a defendant in a high profile case. His ultimate decision was cast as racial treason because it burdened a fellow black person. The story was set in motion when Steven Roth hired two black men in 1986, Darren Norman and Steven Bowman, who disfigured the face of Marla Hanson, a white female. ${ }^{178}$ Hanson, the ex-model, became the target of her landlord Roth's ire, when she pressed for the return of her $\$ 850$ security deposit and rejected his flirtatious advances. ${ }^{179}$ After Roth's conviction of first-degree assault, Bowman and Norman were tried jointly for their role in the crime. ${ }^{180}$ Each had their own black attorney. Alton Maddox ${ }^{181}$ represented Bowman and

168. Id.

169. Ohio v. Ward, 1986 Ohio App. LEXIS 9836, at 1* (Ohio Ct. App., 1986).

170. Id.

171. Id.

172. Id.

173. $I d$.

174. Id. at 2 .

175. Id. at 3 .

176. Id. at 4 .

177. Id. at 5 .

178. Todd S. Purdum, Model Slashed, an Ex-Landlord is Among 3 Held, N.Y. TIMES, June 6. 1986, at 3B.

179. Robert D. McFadden, Wounded Model Retains her Faith in Career and City, N.Y. Times, June 7, 1986, at 29; Kirk Johnson, Prosecutor Says Rejection Caused Razor Assault on Fashion Model, N.Y. TIMES, Nov. 25, 1986, at 2B.

180. Kirk Johnson, Slashed Model Accused of Race Bias by Defense, N.Y. TIMES, Mar. 22,1987 , at 34 .

181. Associated Press, Defense Lawyer Says He Is 'the Victim', N.Y. TIMES, Mar. 28, 1987 , at 31 . 
Plummer Lott represented Norman. ${ }^{182}$ Throughout the three-month trial, both Maddox and Lott argued that Roth was the assailant and that the two defendants were framed by the police and Maddox's foe, Manhattan District Attorney Robert Morgenthau. ${ }^{183}$ But during his closing argument, Lott, in stunning fashion, attempted to pin the crime entirely on Bowman. ${ }^{184}$ Maddox was livid. ${ }^{185}$ Bowman's family and blacks in the courthouse jeered Lott, calling him an "Uncle Tom" and a "snitch.", Lott's detractors, that is, depicted his shocking maneuver as an instance of racial betrayal.

Shrugging off the criticism, Lott noted that his "obligations runs to [his] client." 187 But, because Lott laid blame on his client's co-defendant who happened to be black, he was branded an Uncle Tom. If Lott and Maddox agreed to not pin the crime on the other, Lott's gambit was indeed treacherous. But it was not racial treachery. If his client's co-defendant was white, it is highly unlikely Lott would have been criticized. The voracity of Lott's legal defense should not have been limited by melanin of his client's cohorts. And Lott did not owe Maddox's clients any special deference because of racial commonality.

\section{Whose Side Are You On Anyway?}

Other times blacks were denounced for racial treachery for violating a norm that required that blacks be on the "black" side of a racial divide. As was often true during this period, this norm operated destructively. Defense attorney Michael Batchelor from Detroit, was denounced as an Uncle Tom for such reasons. In 1993, blacks in Detroit attempted to convince Michael Batchelor to stop defending a white cop accused of murdering a black man. ${ }^{188}$ Batchelor, many concluded, had crossed the line and endured endless attacks on his racial fidelity. ${ }^{189}$ A car full of black teenagers, for example, spotted him and one shouted, "That's the bastard representing the white cops! We ought to beat HIS ass to death." "Uncle Tom" whispers were inaudible. ${ }^{191}$ His peers-black attorneys-were likewise unsupportive. ${ }^{192}$ Attorney Jeffrey Edison said that historical brutality

182. Kirk Johnson, Slashed Model Cross-Examined in Attack Trial, N.Y. TIMES, Mar. 27, 1987, at 24B.

183. Peter Noel, Was Maddox Betrayed in Model Slashing Case?, N.Y. AMSTERDAM NEWS, May 16, 1987, at 1.

184. Id.

185. Id.

186. Id.

187. Id.

188. Julia Prodis, Black Lawyer Called 'Traitor' for Representing White Cop, ASSOCIATED PRESS, July 25, 1993.

189. Id.

190. Id.

191. Id.

192. See id. 
against black men done under the guise of law enforcement would have rendered him unable to defend a white cop accused of murdering a black man. ${ }^{193}$

The basic grievance against Batchelor was that to assist a white cop in his attempt to escape punishment for killing a black man was to enliven the historical specter of whites murdering blacks with no punishment. ${ }^{194}$ Batchelor, in other words, was a willing participant in a painful narrative wherein there was little chance that white assailants would ever be brought to justice for crimes against blacks. Batchelor admitted that the condemnation was painful but felt that his representation was tantamount to betrayal. ${ }^{195}$ "If a white man can't get a fair trial," he questioned, "how can a black man ever expect to?"196

Along those lines was Philadelphian Judge Abram Frank Reynolds, known as a straightforward jurist and among the area's most respected jurists. ${ }^{197}$ His lenient sentencing of two white teenagers found guilty of raping an 11-year old black girl resulted in him being branded as an Uncle Tom. ${ }^{198} \mathrm{He}$ sentenced the two rapists to undergo sex-offender treatment, residential treatment, house arrest, and lengthy court supervision but no jail time. ${ }^{199}$ The punishment was considered perplexingly lenient and for this, detractors called him an "Uncle Tom" and a traitor to his race. ${ }^{200}$ A man true to his race, one is left to assume, would have punished the rapists more severely. There was no evidence, though, that his easy sentencing violated any of the three constructive racial loyalty norms. Reynolds might have exercised bad judgment in sentencing. That potential mistake, however, is not necessarily tantamount to racial betrayal. His detractors, in short, failed to successfully prosecute him for betrayal.

Sometimes black cops were wedged in awkward positions, forced to defend and protect those they undoubtedly found personally repugnant. These dilemmas left them highly exposed to Uncle Tom charges. One such scenario occurred when black cops were forced to defend the Ku Klux Klan from black protestors. The events began in 1990, when U.S. District Judge Louis Oberdorfer permitted the KKK to march between the Washington Monument and the Capitol in Washington D.C. ${ }^{201}$ D.C. officials wanted to limit the march to four blocks, fearing that the city would fail to keep the peace between the inevitable

193. Id.

194. See id.

195. Id.

196. Id.

197. Jacqueline Soteropoulos, Judge dedicated to children calls it a career. Abram Frank Reynolds saw no high professional calling than Family Court, PHILA. INQUIRER, July 19, 2003, at B01.

198. Id

199. Id.

200. $I d$.

201. Mary Jordan \& Linda Wheeler, 14 Hurt as Anti-Klan Protestors Clash with Police, WASH. POST, Oct. 29, 1990, at A1. 
protestors and the Klan. ${ }^{202}$ D.C. officials' prediction was correct; ${ }^{203}$ over a thousand protested the KKK march and the police struggled to quell the violence. ${ }^{204}$ Some demonstrators threw rocks at the Klan, but the cops were frequently pelted instead and, in fact, one police officer was trapped for 15 minutes in his police car being bombarded with projectiles. ${ }^{205}$ The cops, responding to the violence from some of the protestors, pushed the crowd back to maintain order. ${ }^{206}$ But being put in the position to defend the Klan rendered black cops the objects of ridicule. ${ }^{207}$ "All these people were throwing bottles and calling us 'Uncle Tom,"” one officer said. ${ }^{208}$ "We couldn't put our personal beliefs into the situation. I'm hoping they [the Klan] don't come back any time soon. It was rough." 209 Black cops, otherwise stated, were unfairly scolded for correctly doing their jobs, which incidentally required them to be physical with black protestors.

Though the previous examples underscore the point, none demonstrate how the black insider was often criticized more than the treatment of Christopher Darden, the bedeviled O.J. Simpson prosecutor. As Elise Cose cleverly scribes, "the endless media coverage and Darden's subsequent best-selling book created a compelling and indelible portrait of the black prosecutor as a tortured soul - as a conflicted laborer in a perfidious place where celebrity, crime, and conflicting racial perceptions collide." 210 Blacks would dissect the evidence; they would evaluate it earnestly; and they would conclude that O.J. Simpson was guilty of double homicide. Darden sincerely believed the truth was obvious. In a book about his role in the Simpson trial, Darden penned, "I had believed that African Americans were the most just people on the planet and that they would convict a black icon when they saw the butchery, the pattern of abuse, and the overwhelming evidence." 211

Darden, however, miscalculated. "I was branded an Uncle Tom," he wrote, "a traitor used by The Man.",212 He received faxes saying, "You're an Uncle Tom.",213 People telephoned him calling him an "Uncle Tom," warning, "don't ever refer to yourself as black, "cause you ain't," and asking, "How

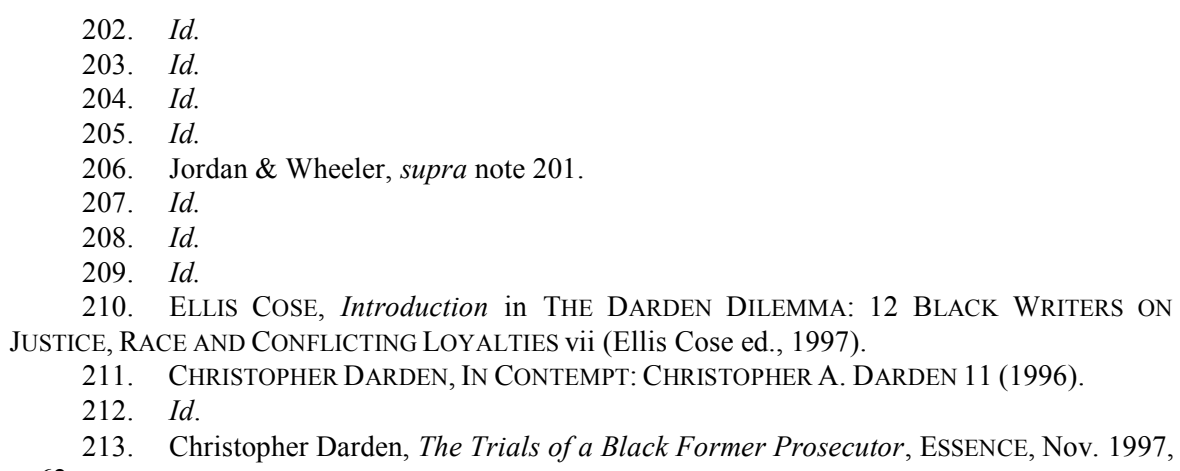


could you allow yourself to be used like that?"214 Between blacks and whites, there was a fault in public opinion of whether Simpson was guilty. The invective that Darden received was undoubtedly amplified because he was chosen as the prosecutor against Simpson, at least in part, many felt, because he was black and could, therefore, make arguments that a white prosecutor could not. ${ }^{215}$ For being on the side that sought to punish Simpson, who many blacks felt was framed by the racist LAPD, Darden was persona non grata in his own community. But, of course, prosecuting O.J. Simpson did not, in any way, approach duplicity.

\section{The Black Spokesman}

Various instances have occurred where individual blacks held themselves out as the arbiters of blackness, defining the normative code of conduct in a specific situation. Norm violators were deemed traitors and Uncle Tom denunciation was prompt and unrelenting. In these scenarios, the supposed Uncle Toms did not necessarily even retain positions within the criminal justice system. The asserted Uncle Toms, rather, could be participants in a criminal justice debate who possessed a voice that "behavior moderators" found necessary to supervise. According to this racial loyalty norm, blacks, in short, were required to embrace the position announced by a self-proclaimed agent for the race. Noncompliance signaled disloyalty and violated a social norm. But, as true with the others of this era, this norm was destructive.

Perhaps the best example of this sort of norm stems from a now infamous hoax. In the late 1980s, Tawana Brawley gained national attention after claiming that six white men, including one police officer, sexually assaulted her. ${ }^{216}$ A grand jury subsequently concluded that she had concocted the entire tale. ${ }^{217}$ Until the deception was revealed, however, the controversial allegation consumed the state of New York. Al Sharpton, the bombastic Harlem activist, ramped up the noise level, riling up black anger by playing on black resentment. ${ }^{218}$ Sharpton's goal was clear- he wanted to define the parameters of the

214. DARDEN, IN CONTEMPT, supra note 211, at 11

215. WILLIAMS, supra note 181 at 5, 265.

216. Esther Iverem, Bias Cases Fuel Anger of Blacks, N. Y. TIMES, Dec. 14, 1987, at B1. The Tawana Brawley incident has been written about ad nasuem. See generally MIKE TAIBBI \& ANNA Sims-Phillips, UnHOly ALliances: WORKING THE TAWANA BRAWLEy STORY (1989); Robert D. MCFAdden, Outrage: The Story Behind the TAwana Brawley HoAX (1990); Edwin Diamond, The Brawley Fiasco, N.Y. MAG., Jul. 18, 1988, at 20.

217. Robert D. McFadden, Brawley Made up Story of Assault, Grand Jury Finds, N. Y. TiMES, Oct. 7, 1988, at A1.

218. Sharpton, in his memoir, argues that the Brawley incident has unfairly tarnished his record of standing against injustice. Sharpton writes,

I have marched for justice in Howard Beach. I have marched for justice in Bensonhurst. I have fought for justice for men like Abner Louima and Amadou Diallo. I shed a light on racial profiling throughout this country. I have spent ninety days in prison in protest over bombings in Vieques. I have even fought for justice for the workers of Enron who were scammed out of their 
debate and incite outrage. Some blacks, though, charged him with unnecessarily forging racial animosity. Assemblyman Roger Green upbraided Sharpton for his biting statements and "tactics that encourage race war." 19 Green, Sharpton retorted, was a "state-sponsored Uncle Tom."220 Governor Mario Cuomo said he conversed with other black ministers who found Sharpton's public pronouncements deplorable. ${ }^{221}$ These clergymen, however, relayed their concerns privately to Cuomo, because according to the Governor, "They were . . concerned that they'll be called 'Uncle Toms.",222 Members of the local chapter of the NAACP also criticized Sharpton's tactics and were called "Uncle Toms" and "Aunt Thomasinas.,"223

This was not the only time Sharpton attempted to marginalize his foes with Uncle Tom allegations. A few years later, Sharpton and his associate, attorney Alton Maddox, travelled to New Jersey to rail against injustice in the criminal justice system there. And they packed Uncle Tom with them. On April 10, 1990, Phillip C. Pannell, a black teenager, was shot in the back while running away from Gary Spath, a Teaneck, New Jersey police officer. ${ }^{224}$ While Sharpton and Maddox inflamed the wound, others opted to soothe it. ${ }^{225}$ Jesse Jackson, for instance, strove to ease tensions as did the nearest NAACP chapter. ${ }^{226}$ Sharpton, however, pursued the scorched earth method. "They," Sharpton proclaimed, " are calling on people who can bring calm to the area rather than ask them to demand justice." 227 "Rev. Jackson and others only want us to be quiet," he continued. ${ }^{228}$ Sharpton alleged that there was collusion between the local power structure and "Uncle Toms" in the area to keep the peace. ${ }^{229}$ Sharpton, on the other hand, "intend[ed] to turn the streets inside out until justice is done." $" 230$ Sharpton here defined what the black community's temperament should be-fiery indignation - and the disobedient were disloyal worthy of the most biting pejorative in the black lexicon.

life savings. But the one case that seems to take more precedence over every good I have done in my career is Tawana Brawley. REVEREND Al SHARPTON, Al ON AMERICA 229 (2002).

219. Howard Kurtz, Political Fracas Overshadows New York Probe of Racial Assault, WASH. POST, Mar. 2, 1988.

220. Jeffrey Schmalz, Racial Puzzle for Cuomo, N.Y. TimeS, May 9, 1988, at B1.

221. Id.

222. Jesse Walker, NAACP Counsel Cracks Down on Tawana's Reps, N.Y. AMSTERDAM NEwS, Mar. 19, 1988, at 3.

223. Id.

224. AP, 150 Teaneck Marchers Protest April Shooting, N.Y. TIMES, July 23, 1990, at B4. Spath was acquitted of criminal charges. See Jury Acquits White Cop in Death of N.J. Teen That He Shot in the Back, JET, Mar. 2, 1992, at 26.

225. Simon Anekwe, Al Sharpton Vows March Protest in Teaneck Killing, N.Y. AMSTERDAM NEWS, Apr. 21, 1990, at 1.

226. Id.

227. $I d$.

228. Id.

229. Id.

230. Id. 
The case of a racially motivated murder of a black man in New York City in 1986 also proves instructive in appreciating how some defined the black community's official position in a given situation and punished black dissenters. The first victim was Willie Turks in $1982 .{ }^{231}$ Turks was beaten to death by a group of whites. ${ }^{232}$ The second victim was Michael Griffith, killed in $1986 .{ }^{233}$ Griffith and three friends were beaten by white youths in a white neighborhood. ${ }^{234}$ Griffith died after he was hit by a car as he tried to flee his attackers. $^{235}$ The third was Yusuf Hawkins in 1989. ${ }^{236}$ Hawkins and three friends were beaten by a mob of whites and Hawkins was shot twice in the chest. $^{237}$ Black community leaders successfully pressed Governor Andrew Cuomo to appoint a special prosecutor. ${ }^{238}$ Queens District Attorney John Santucci was the initial prosecutor, but under his stewardship, the case against the alleged perpetrators appeared to be in danger. ${ }^{239}$ Black leaders wanted a special prosecutor because they felt that Santucci "either botched or covered up" what really happened. ${ }^{240}$ Those leaders felt vindicated after the special prosecutor indicted twelve "white thugs" for Hawkins' murder. ${ }^{241}$ Their demand for the special prosecutor was criticized by "New York City's embattled Black police chief and Black 'Uncle Toms and Tomasinas," local public black figures who disagreed with the appointment of the special prosecutor. ${ }^{242}$

The main problem with the Uncle Tom accusations here was that an honest difference of opinion was equated to treachery. A successful case could not be made that these folk were working on behalf of the race's foes, were being inexcusably meek or were apathetic about black people. But because they did not hue the line that the self-appointed spokesmen drew, they were unfairly reprimanded. In an effort to build racial solidarity, blacks must not stifle legitimate debate. The appropriate response to the Tawana Brawley's accusations, for instance, was a conversation black New Yorkers should have had. For one person to declare how black people should react and associate disagreement with selling out was harmful rather than helpful to the cause of racial solidarity. The point of racial solidarity is to get blacks invested in the group and from

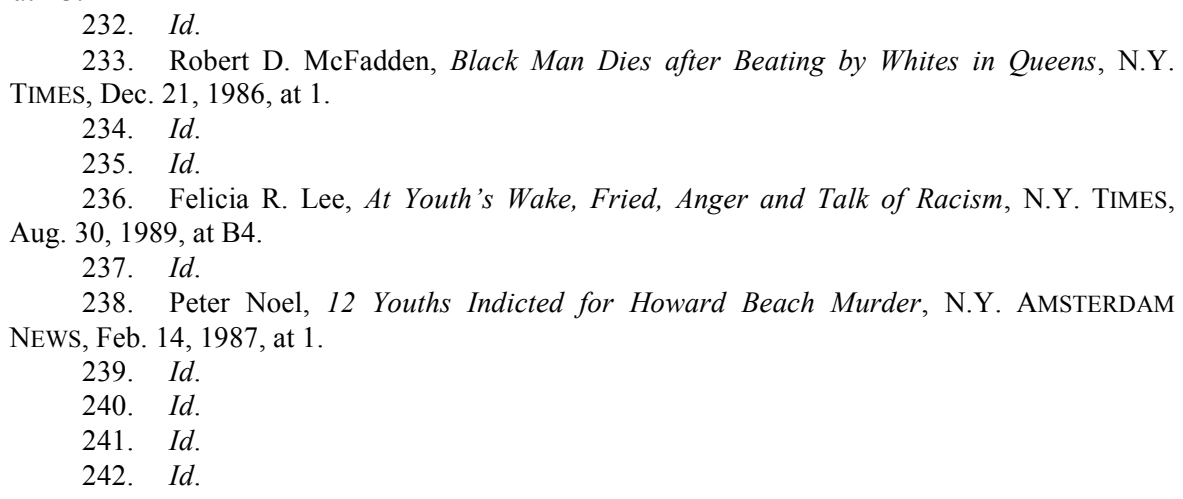


there work together to solve the dilemmas that most afflict the group. One person, or a few people for that matter, should not be able to dictate what will be the black point of view.

\section{CONCLUSION}

One final important inquiry is why norm management has grown increasingly destructive. The best explanation, I think, would be that the sorts of people enforcing racial loyalty norms changed and are, quite frankly, less responsible. The earlier promulgators and enforcers were more conscientious. Charles Evers, for instance, exercised care when dubbing a black cop "Tom" who spied on civil rights activists in Mississippi. The 1960s and 1970s enforcers were sober minds participating in the enforcement of social norms. But afterwards, we see examples of individuals like 2 Live Crew's Luther Campbell, who called a judge an Uncle Tom because the judge deplored his musical content and was not inclined, ostensibly, to be a sympathetic jurist. Even less defensible were the actions of Al Sharpton. The social norms in the 1980s and 1990s were negligently managed because the cast of characters who regulated behavior was not as careful as its predecessors.

Tracing Uncle Tom in the context of the criminal justice system leads to some remarkable stories of black intra-racial behavior. As a subordinated people, blacks devised various strategies to augment their societal standing and make America a better home and a place where they could fully realize their dreams. A section of the black community focused inward, maintaining group solidarity and the intra-racial discipline necessary to mount a sustained challenge to racial inequality. The decision to regulate the community's behavior provides a peek into the various textures that comprise the black American experience and how a subordinate people have assiduously tried to rid itself of indicia of second-class citizenship. 